\title{
Zumhof, Tim
}

\section{Historical culture, public history, and education in Germany and the United States of America. A comparative introduction to basic concepts and fields of research}

Zumhof, Tim [Hrsg.]; Johnson, Nicholas K. [Hrsg.]: Show, don't tell. Education and historical representations on stage and screen in Germany and the USA. Bad Heilbrunn : Verlag Julius Klinkhardt 2020, S. 15-30. - (Studien zur Deutsch-Amerikanischen Bildungsgeschichte / Studies in German-American Educational History)

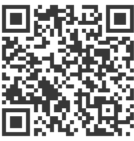

Quellenangabe/ Reference:

Zumhof, Tim: Historical culture, public history, and education in Germany and the United States of America. A comparative introduction to basic concepts and fields of research - In: Zumhof, Tim [Hrsg.]; Johnson, Nicholas K. [Hrsg.]: Show, don't tell. Education and historical representations on stage and screen in Germany and the USA. Bad Heilbrunn : Verlag Julius Klinkhardt 2020, S. 15-30 - URN: urn:nbn:de:0111-pedocs-205089 - DOI: 10.25656/01:20508

https://nbn-resolving.org/urn:nbn:de:0111-pedocs-205089

https://doi.org/10.25656/01:20508

in Kooperation mit / in cooperation with:

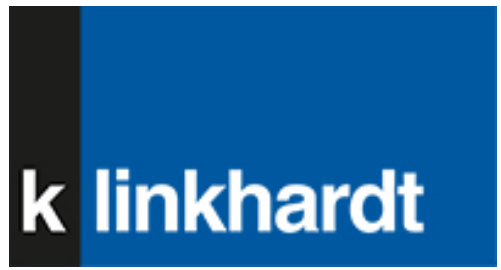

http://www.klinkhardt.de

\section{Nutzungsbedingungen}

Dieses Dokument steht unter folgender Creative Commons-Lizenz: http://creativecommons.org/licenses/by-nc-sa/4.0/deed.de - Sie dürfen das Werk bzw. den Inhalt unter folgenden Bedingungen vervielfältigen, verbreiten und öffentlich zugänglich machen sowie Abwandlungen und Bearbeitungen des Werkes bzw. Inhaltes anfertigen: Sie müssen den Namen des Autors/Rechteinhabers in der von ihm festgelegten Weise nennen. Dieses Werk bzw. der Inhalt darf nicht für kommerzielle Zwecke verwendet werden. Die neu entstandenen Werke bzw. Inhalte dürfen nur unter Verwendung von Lizenzbedingungen weitergegeben werden, die mit denen dieses Lizenzvertrages identisch oder vergleichbar sind.

Mit der Verwendung dieses Dokuments erkennen Sie die Nutzungsbedingungen an.

\section{Terms of use}

This document is published under following Creative Commons-License: http://creativecommons.org/licenses/by-nc-sa/4.0/deed.en - You may copy, distribute and transmit, adapt or exhibit the work in the public and alter, transform or change this work as long as you attribute the work in the manner specified by the author or licensor. You are not allowed to make commercial use of the work. If you alter, transform, or change this work in any way, you may distribute the resulting work only under this or a comparable license.

By using this particular document, you accept the above-stated conditions of use.

\section{Kontakt / Contact:}

\section{peDOCs}

DIPF | Leibniz-Institut für Bildungsforschung und Bildungsinformation

Informationszentrum (IZ) Bildung

E-Mail: pedocs@dipf.de

Internet: www.pedocs.de

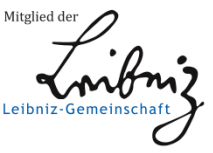




\section{Studien zur Deutsch-Amerikanischen}

Bildungsgeschichte / Studies in German-American Educational History

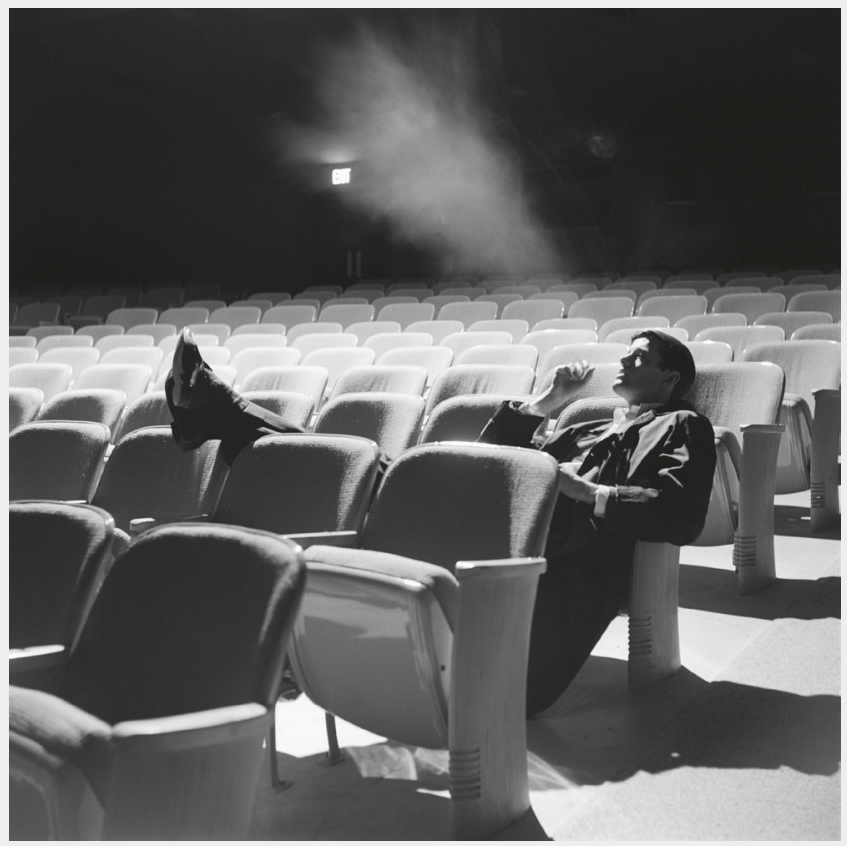

Tim Zumhof

Nicholas K. Johnson (eds.)

Show, Don't Tell

Education and Historical Representations on Stage and Screen in Germany and the USA 


\section{Zumhof / Johnson Show, Don't Tell}


Studien zur Deutsch-Amerikanischen Bildungsgeschichte Studies in German-American Educational History

General Editor Jürgen Overhoff 


\section{Tim Zumhof \\ Nicholas K. Johnson (eds.)}

\section{Show, Don't Tell}

Education and Historical Representations on Stage and Screen in Germany and the USA 
This volume was published in cooperation with the Center for German-American Educational History at the University of Münster.

Titel entstand in Kooperation mit der „Arbeitsstelle für Deutsch-Amerikanische Bildungsgeschichte".

\section{Arbeitsstelle für Deutsch-Amerikanische Bildungsgeschichte}

Dieser Titel wurde in das Programm des Verlages mittels eines Peer-Review-Verfahrens aufgenommen. Für weitere Informationen siehe www.klinkhardt.de.

Bibliografische Information der Deutschen Nationalbibliothek

Die Deutsche Nationalbibliothek verzeichnet diese Publikation in der Deutschen Nationalbibliografie; detaillierte bibliografische Daten sind im Internet abrufbar über http://dnb.d-nb.de.

2020.lg. (C) by Julius Klinkhardt.

Bildnachweis Umschlagseite 1: (C) Francis Miller (1961). Peter Fonda in theater audience seats at Omaha Nebraska Community Playhouse. The LIFE Picture Collection via Getty Images. - The cover photo is used for illustrative purposes only and does not represent an endorsement by the Peter Fonda estate.

Druck und Bindung: AZ Druck und Datentechnik, Kempten.

Printed in Germany 2020.

Gedruckt auf chlorfrei gebleichtem alterungsbeständigem Papier.

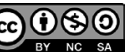

Die Publikation (mit Ausnahme aller Fotos, Grafiken und Abbildungen) ist veröffent-

licht unter der Creative Commons-Lizenz: CC BY-NC-SA 4.0 International

https://creativecommons.org/licenses/by-nc-sa/4.0/

ISBN 978-3-7815-5828-1 Digital

doi.org/10.35468/5828

ISBN 978-3-7815-2397-5 Print 


\section{Table of Contents}

Nicholas K. Johnson and Tim Zumhof

"Are you not entertained?" -

Education, Entertainment, and Historical Representations

on Stage and Screen in Germany and the USA, an Introduction .7

Tim Zumbof

Historical Culture, Public History, and Education

in Germany and the United States of America.

A Comparative Introduction to Basic Concepts and Fields of Research.

Jürgen Overhoff

"Geschichte ist etwas Fließendes."

Lion Feuchtwanger's Changing Understanding of History

and the Role of the Stage: From his Earliest Theatrical Productions

to his Play Waffen für Amerika (1943/44)

Simon Richter

Duell an der Havel:

Fritz von Unruh's Depiction of Eighteenth-Century

Prussian-American Relations

Alissa Rubinstein

The 614th Commandment:

A Documentary Play about how American Jews Feel

about Germany Today

Wolfgang Hochbruck

Living History as an Educational Tool and Method

in North America and Germany

Stephanie Johns

Theatre, Education, and Public History:

Teaching History at the Stratford Festival 
6 Table of Contents

Felix Apel

Hollywood's Influence on the Transmission of Historical Images:

Lars Kraumes' Der Staat gegen Fritz Bauer

Thorsten Carstensen

Learning from John Ford:

History, Geography, and Epic Storytelling in the Works of Peter Handke

Raymond Haberski, Jr.

The Passion of Richard Schickel: What We Expect from War Films

160

Nicholas K. Johnson

"A classroom history lesson is not going to work":

HBO's Conspiracy and Depicting Holocaust Perpetrators on Film

Table of Figures

List of Contributors

Index

Acknowledgements 


\section{Tim Zumhof}

\section{Historical Culture, Public History, and Education in Germany and the United States of America. A Comparative Introduction to Basic Concepts and Fields of Research}

In 2013, the German artist Christian Jankowski invited members of the Polish national weightlifting team to lift a number of massive public sculptures in the capital of Warsaw. These included several communist-era memorials, statues of Ronald Reagan and Willy Brandt, and the figure of "Syrenka" the Mermaid, a famous symbol of the city. Wearing their national colors, red and white, the Polish weightlifters struggled to elevate these bulky bronze and brick monuments, "metaphorically attempting to lift the very burden of history on to their shoulders." 1 Under the title Heavy Weight History, Jankowski combined photographs, documents, and a 25-minute film for an art installation which records the weightlifters' attempts at lifting monuments representing Polish history. Jankowski succeeds in disrupting and initiating debates on the still-raw history of Poland's occupation by the Nazis, as well as the country's era of Soviet domination after World War II. Jankowski's film gives a "light-hearted and socially-inclusive" complexion to his controversial undertaking of "reinvigorating locals' relationships to oft-neglected bits of Varsovian public statuary."

Jankowski's art installation is an example of the broad and public interest in history worldwide. Interest in history grew in the 1980s and peaked in the second half of the 1990s: visitor counts to historical exhibitions and museums increased, and a considerable public interest in historiographical controversies (e.g. Historikerstreit, Wehrmachtsausstellung, Enola Gay exhibition) arose. ${ }^{3}$ Today, people experience history in various forms, such as magazines ${ }^{4}$, contemporary $\operatorname{art}^{5}$, and video

1 Lisson Gallery. “Christian Jankowski: Heavy Weight History,” 2014, URL: https://www.lissongallery.com/exhibitions/christian-jankowski-heavy-weight-history (accessed August 28, 2019).

2 Lisson Gallery, "Christian Jankowski."

3 See Barbara Korte and Sylvia Paletschek. "Geschichte in populären Medien und Genres: Vom Historischen Roman zum Computerspiel," in History Goes Pop. Zur Repräsentation von Geschichte in Medien und Genres, ed. by Barbara Korte and Sylvia Paletschek (Bielefeld: transcript, 2009), 9.

4 See Robert Thorp. "Popular history magazines and history education." Historical Encounters: A journal of historical consciousness, historical cultures, and history education 2 (2015): 102-112.

5 See Rebecca Bush and K. Tawny Paul. Art and Public History. Approaches, Opportunities, and Challenges (Lanham: Rowman \& Littlefield, 2017). 
games. ${ }^{6}$ History has found a new popular outlet on TV and online streaming services. One could even say "that more people encounter history as 'edutainment' now than through formal education." In Germany and the United States, different approaches have emerged to analyze and organize these cultural ways of "doing history."

Since the 1970s, a group of German historians has attempted to widen the scope of history didactics (Geschichtsdidaktik) - an academic field that examines how to teach history and train history teachers. Some historians called for including research on how people encounter history outside the classroom and school curriculum. At the same time, public history became an institutionalized and diverse field of research and practice in the US. It included different ways of applying history to current issues, engaging public audiences in history and memory, and bringing the various skills of historians into use. In the following, a comparison of these theoretical reflections and practical frameworks sheds light on the question of whether and how they address educating people about history via popular media like television, cinema, and theater.

\section{Outside the Classroom: Historical Culture}

The umbrella term historical culture (Geschichtskultur, culture historique, cultura histórica) refers to the different ways people deal with history. It is a "holistic meta-historical concept" that comprises people's relationships with the past. This means more than just historiography or a purely academic approach to history. Historical culture stands for the various manifestations of history in social life. It includes all forms and practices of representing, communicating, remembering, and experiencing history in a society. If culture is the way societies interpret, transmit, and transform reality, historical culture is the specific way in which societies relate to their pasts. By examining historical culture, we investigate the social production of historical experience and its objective manifestations.

6 See Dawn Spring. "Gaming history: computer and video games as historical scholarship." Rethinking History. Journal of Theory and Practice 19 (2015): 207-221.

7 Barbara Korte and Sylvia Paletschek, "Historical Edutainment: New Forms and Practices of Popular History?" in Palgrave Handbook of Research in Historical Culture and Education, ed. by Mario Carretero et al. (London: Palgrave Macmillan, 2017), 191.

8 See Stefanie Samida, Sarah Willner, and Georg Koch. "Doing History - Geschichte als Praxis. Programmatische Annäherungen," in Doing History. Performative Praktiken in der Geschichtskultur, ed. by Sarah Willner, Georg Koch, and Stefanie Samida (Münster: Waxmann, 2016), 4-7.

9 Maria Grever and Robert-Jan Adriaansen. "Historical Culture: A Concept revisited," in Palgrave Handbook of Research in Historical Culture and Education, ed. by Mario Carretero, Stefan Berger, and Maria Grever (London: Palgrave Macmillan, 2017), 77. 
Cultural ways of dealing with history have always been around; humans have always used different means to represent, communicate, remember, and experience history. Bernd Schönemann, Professor of History Didactics and Historical Culture at the University of Münster, pointed out that the concept of historical culture has a great diachronic depth. ${ }^{10}$ That means that historical cultures themselves change throughout history. In other words, we can examine the history of how people looked at their histories. Behind these various ways of remembering, experiencing, communicating, and representing history lie different understandings and conceptions of history. They are specific interpretations of the relationship between the temporal dimensions of past, present, and future that determine, on the one hand, a degree of human agency, and on the other hand, the epistemological possibilities of knowing the past.

Schönemann differentiates roughly three ideal-typical conceptions: The pre-modern conception (history as use-value), which Cicero expressed prominently with the topos Historia magistra vitae. Here, the past serves as a depot of experiences and moral lessons to guide future-oriented actions in the present. The Prussian diplomat Joseph Maria von Radowitz (1797-1853) exemplified the modern conception (history as knowledge) in a remark on Hegel: From history, you only learn history ("Aus der Geschichte lernt man eben nur Geschichte"). The model character of the past collapsed and was replaced by the uniqueness of historical processes. ${ }^{11}$ The post-modern conception (history as event), Schönemann argues, accentuates the mediation of history. You do not learn from history, but experience it in different medial ways.

However, the theoretical reflections on historical culture as a research subject first began with the West German debates on history didactics in the 1970s. ${ }^{12}$ The discussion about widening the scope of history didactics started with Karl-Ernst Jeismann's talk on "historical consciousness in society" at the 1976 conference of German Historians (Deutscher Historikertag) in Mannheim and the conference for history didactics (Tagung der Konferenz für Geschichtsdidaktik) on "history and the public" (Geschichte in der Öffentlichkeit) the following year. ${ }^{13}$ Up to this point, historical knowledge was regarded purely as the product of professional historians and questions about teaching history focused on how history teachers can efficiently transmit a traditional or prescribed canon of approved or ideolog-

10 See Bernd Schönemann. "Erinnerungskultur oder Geschichtskultur?" in Kulturwissenschaft und Geschichtsdidaktik, ed. by Eugen Kotte (München: Martin Meidenbauer, 2011), 58.

11 See Reinhart Koselleck. "Historia Magistra Vitae. Über die Auflösung des Topos im Horizont neuzeitlich bewegter Geschichte," in Vergangene Zukunft. Zur Semantik geschichtlicher Zeiten, ed. by Reinhart Koselleck (Frankfurt am Main: Suhrkamp, 1979), 56.

12 See Jörn Rüsen. "The Didactics of History in West Germany: Towards a New Self-Awareness of Historical Studies." History and Theory 26 (1987): 275-286.

13 See Rauthe, Public History, 167-172. 
ically-suitable content. Jeismann suggested that history didactics should expand its field of research and focus on the formation and transformation of historical consciousness (Geschichtsbewusstsein). ${ }^{14}$ Since then, the term "historical consciousness" has become a key concept in history education. It does not only refer to the sheer mastery of basic historical information and the ability to argue historically, but it also depicts much more of an awareness of the historical nature of human behavior, knowledge, institutions, events, and developments in society, including one's own identity. Historical consciousness encompasses the interconnection between an interpretation of the past, an understanding of the present, and a prospect for the future. Jeismann pointed out that teaching history in schools is only one part of that which contributes to create and change historical consciousness. Hence, history didactics should include contexts outside the classroom. ${ }^{15}$

However, historical culture did not become a key concept within the history didactics field until the 1990s. In 1991, German historian and main proponent of the concept, Jörn Rüsen, defined historical culture as an external aspect of historical learning. He underlined the bimodal reconstruction of history and pointed out that historical learning has two sides. The inner side refers to historical consciousness (Geschichtsbewusstsein), the outer to historical culture (Geschichtskultur). Both aspects are two sides of the same coin. For Rüsen, historical consciousness refers to an individual mental structure and a coherent set of operations which emerge from processes of internalization and socialization (from the outside to the inside). It cannot be merely equated with historical knowledge of the past. It instead structures historical knowledge as a medium to understand the present and to anticipate the future. It plays an important role in mental processes that shape one's own identity and undertakes essential functions in human culture. ${ }^{16}$ Historical culture, is otherwise a collective effort which manifests itself through externalization (from the inside to the outside). It includes institutions and organizations that form the infrastructure of historical learning. It comprises the various ways in which historical consciousness articulates itself in society: in schools and textbooks, museums and exhibitions, the culture industry and mass

14 See Karl-Ernst Jeismann. "Didaktik der Geschichte. Die Wissenschaft von Zustand, Funktion und Veränderung geschichtlicher Vorstellungen im Selbstverständnis der Gegenwart," in Geschichtswissenschaft. Didaktik - Forschung - Theorie, ed. by Erich Kosthorst (Göttingen: Vandenhoeck \& Riprecht, 1977), 9-33. - For the differences, overlaps and synergies of the concepts Historical Thinking and Historical Consciousness, see Peter Seixas. "Historical Consciousness and Historical Thinking," in Palgrave Handbook of Research in Historical Culture and Education, ed. by Mario Carretero, Stefan Berger, and Maria Grever (London: Palgrave Macmillan, 2017), 59-72.

15 See Karl-Ernst Jeismann. "Geschichtsbewußtsein als zentrale Kategorie der Didaktik des Geschichtsunterrichts," in Geschichte und Bildung. Beiträge zur Geschichtsdidaktik und zur Historischen Bildungsforschung, ed. by Wolfgang Jacobmeyer and Bernd Schönemann (Paderborn: Schöningh, 2000), 46-72.

16 See Rüsen, “The Didactics of History,” 284-285. 
media, anniversary celebrations, and so on. ${ }^{17}$ Thus, Rüsen defines historical culture as "the complete range of activities of historical consciousness." 18

Even if individuals ignore historical monuments, refuse to participate in anniversary celebrations, or do not visit historical sites or museums, these parts of historical culture still exist. They do so independently from our personal perception; they have greater durability; they are more consistent than the historical imaginations of individuals and can even exceed the capacity of individuals to store memory and, furthermore, prevent historical amnesia.

In this case, Rüsen's concept of historical culture shows close connections to the field of memory studies and to concepts like cultural memory. ${ }^{19}$ Since Maurice Halbwachs' and Aby Warburg's studies on collective and social memory in the 1930s, memory studies have become a field of research for historians and other scholars in the humanities. Jan Assmann, for example, differentiates between three levels of memory: individual, communicative, and cultural memory. ${ }^{20} \mathrm{Com}$ municative memory depends on socialization and communication, and it can be analyzed as a function of social life. It enables us to live in social groups and communities. It is characterized by its proximity to the everyday. Cultural memory is also shared by a number of people, but it is a

kind of institution. It is exteriorized, objectified, and stored away in symbolic forms that, unlike the sounds of words or the sight of gestures, are stable and situation-transcendent: They may be transferred from one situation to another and transmitted from one generation to another. ${ }^{21}$

Of course, groups of people and communities do not "have" a memory, but they tend to "make" themselves one via things meant as reminders, such as monuments, museums, libraries, archives, and other mnemonic infrastructures that are anchored in time and space. ${ }^{22}$

17 See Jörn Rüsen. "Geschichtsdidaktik heute - Was ist und zu welchem Ende betreiben wir sie (noch)?" in Bildungsgeschichte und historisches Lernen, ed. by Ernst Hinrichs and Wolfgang Jacobmeyer (Frankfurt am Main: Moritz Diesterweg, 1991), 17.

18 See Jörn Rüsen. "Geschichtskultur," in Handbuch der Geschichtsdidaktik. 5" edition, ed. by Klaus Bergmann, Klaus Fröhlich, Annette Kuhn et al. (Seelze-Velber: Kallmeyer’sche Verlagsbuchhandlung, 1997), 38, quoted in Grever and Adriaasen, "Historical Culture: A Concept revisited," 75.

19 See Jan Assmann. "Collective Memory and Cultural Identity," New German Critique 65 (1995), 125-133.

20 See Jan Assmann. "Communicative and Cultural Memory," in Cultural Memory Studies. An International and Interdisciplinary Handbook, ed. by Astrid Erll and Ansgar Nünning (Berlin, New York: De Gruyter, 2008), 109.

21 Assmann, "Communicative and Cultural Memory," 111.

22 See Grever and Adriaasen, "Historical Culture: A Concept revisited," 79-81. 
In the past, several scholars pointed to the opposition between history and memory. ${ }^{23}$ On the one hand, memory is present-oriented, emotionally charged, and non-universal, since it is supported by social groups and therefore constantly changing. It is entangled in conflicts of interest and struggles for power; it has a normative quality and can influence people's understanding of their identity. On the other hand, history as the product of academic discourse is bound to methodological regulations and the advancement of knowledge. Thus, historiography often does not satisfy society's need for historical knowledge providing points of reference. It tends to disconnect itself from public discourse.

Rüsen tried to overcome this rift between history and memory by redefining his concept of historical culture. ${ }^{24}$ For heuristic purposes, he promoted a subdivision of historical culture into five ideal-typical dimensions in which historical consciousness creates meaningful orientations: He distinguishes cognitive, aesthetic, political, moral and religious dimensions. These aspects correlate with five fundamental anthropological operations: thinking, feeling, wanting, judging, and believing. Rüsen notes that various dimensions can intersect and overlap in different elements of historical culture. For example, historiography (or academic writing on history) is bound to methodological conventions and the pursuit of historical "truth" - therefore it is part of the cognitive dimension of historical culture. However, historiography, which uses rhetorical and stylistic devices, can be commented on from an aesthetic point of view. ${ }^{25}$ In this sense, Rüsen states that dimensions of historical culture can intersect, suppress, or absorb each other. Because of this diversity and entanglement, Rüsen suggests that researching historical culture is a multidisciplinary task. Although he argues for establishing different fields of research like the theory, aesthetics, politics, ethics, and theology of history, he does not include an educational or pedagogical dimension to his subdivisions of historical culture. Rüsen does not suggest a pedagogy of history. He probably neglects this dimension because for him, historical culture already is one side of historical learning and in this regard, all aspects of historical culture are related in some way to educational questions. Nevertheless, a look from a purely educational point of view on historical cultures allows us to focus on the possibilities and limitations of intergenerational exchanges. These exchanges are by no means one-way, but rather a continuing dialogue between different generations. They are not just characterized by the way cultural content, practices, or things are handed down from

23 See Wulf Kansteiner. "Finding Meaning in Memory: A Methodological Critique of Collective Memory Studies." History and Theory 41 (2002): 179-197. See also David Lowenthal. "History and Memory." The Public Historian 19 (1997): 31-39.

24 See Jörn Rüsen. "Die fünf Dimensionen der Geschichtskultur," in Angewandte Geschichte. Neue Perspektiven auf Geschichte in der Öffentlichkeit, ed. by Jacqueline Nießer and Juliane Tomann (Paderborn: Schöningh, 2014), 46-57. See also Rüsen, “Geschichtskultur,” 38-41.

25 Rüsen, "Geschichtskultur," 39-40. 
one generation to the next, but also by sustainably transforming these traditions. Pedagogical challenges arise where traditions no longer find any connection to the lifeworld of the younger generation. Social conflicts even develop where there is disagreement over which traditions must be preserved or transformed in which way and to what extent.

\section{Outside Academia: Public History}

While the concept of historical culture is mainly a continental approach, Public History has been an institutionalized field of research, practice, and higher education in the United States since the 1970s. "Public History refers to the employment of historians and the historical method outside of academia: in government, private corporations, the media, historical societies and museums, even in private practice." ${ }^{26}$ It has become a "catch-all phrase that can cover any historical activity that is not regarded as academic history." ${ }^{27}$

In the early twentieth-century United States, long before public history became a general term for historical activities outside academia, an established network of local historians and historical societies existed. For example, historians worked for the National Park Service. In 1933, the National Park Service obtained full responsibility for national historic sites, parks and memorials. This caused an unprecedented need for trained historians who had to locate, identify, evaluate, and research possible historic sites. Likewise, many historians worked in military organizations or even in the private sector for businesses like Firestone, Coca-Cola, Ford Motor Company, and many others. ${ }^{28}$

Although historians working outside of academia had their own associations - like the American Association for State and local History (AASLH), the American Association of Museums (AAM) or the Society of American Archivists (SAA) -, there was neither a common ground nor a specific label for their practice. ${ }^{29}$

The term Public History originally appeared in the 1970s. In the wake of $1960 \mathrm{~s}$ political activism, issues like minority rights, discrimination, and feminism increasingly influenced some historians. It triggered a new emphasis on the history of the disenfranchised, of the poor, of women, of the colonized, and of the)

26 Robert Kelley. "Public History: Its Origins, Nature, and Prospects." The Public Historian, 1 (1978): 16.

27 Faye Sayer. Public History: A Practical Guide (London: Bloomsbury, 2019), 3.

28 See Thomas Cauvin. Public History. A Textbook of Practice (New York, London: Routledge, 2016), 6-7.

29 See Michael C. Scardaville. "Looking Backwards Toward the Future: An Assessment of the Public History Movement." The Public Historian 9 (1987): 39. See also Simone Rauthe. Public History in den USA und der Bundesrepublik Deutschland (Essen: Klartext, 2001) 85. 
enslaved. A consequence of this emergence of new social, feminist, and black histories was a new interest in ordinary people. ${ }^{30}$ More and more, historians rejected the conventional practice of writing history of "great men" - of politicians, thinkers and generals. A striking symbol for this newfound interest of historians in the history of ordinary people was the approach of oral history. ${ }^{31}$ Oral history is a way of gathering historical information about individuals, families, events, or everyday life by interviewing contemporary witnesses. This approach aims to preserve personal stories which would have otherwise been lost and tries to shed light on the experiences of people historians had previously ignored.

With this change in historical research and its links to class conflicts and racial divides, history started playing a more important role in contemporary political debates. For example, historians like C. Vann Woodward were engaged in the Civil Rights Movement. In his book The Strange Career of Jim Crow (1955), Woodward contended that racial segregation did not emerge immediately after the Civil War ended and that it was not embedded in the folkways of the South. He argued that race relations had instead evolved during the generation after Reconstruction the re-integration of the southern states with the Union. This implied "a period of flux in race relations that might have yielded a different outcome, had there been different leadership or different circumstances." ${ }^{32}$ This kind of social history highlighted the links between history, political activism, and even policymaking. In other words, history can be a powerful tool to address social injustice and inspire social progress. This new approach to historical study, which changed the estranged relationship between the public and history, was later referred to as the Public History Movement.

The institutionalization of public history began at the University of California Santa Barbara (UCSB) ${ }^{33}$ and much less visibly at the Carnegie Mellon University in Pittsburgh, Pennsylvania (CMU) ${ }^{34}$ in 1976. Alongside the economic crises at that time, a shrinking market of tenure-track jobs for historians inside academia forced many doctoral programs to decrease their numbers of students. Robert Kelley, History Professor at UCSB, attempted to expand professional employment for historians by linking historical study to the idea of a public rather than aca-

30 See Laurence Veysey. "The 'New' Social History in the Context of American Historical Writing." Reviews in American History 17, 1 (1979): 1-12.

31 See Cauvin, Public History, 7.

32 Sheldon Hackney, Anne Frior Scott, Bertram Wyatt-Brown, William S. McFeely, and Lawrence N. Powell. “C. Vann Woodward, 1908-1999: In Memoriam.” Journal of Southern History 66 (2000): 211.

33 See Kelley, "Public History," 24-28. See also Rauthe, Public History, 88-95.

34 See Peter N. Stearns and Joel A. Tarr. "Curriculum in Applied History: Toward the Future," The Public Historian 9 (1987): 111-125. 
demic career. ${ }^{35}$ With the help of G. Wesley Johnson, Kelley established a graduate program in public history at UCSB in $1976 .{ }^{36}$ This public history graduate studies program included "close instruction in what is the historian's principle skill, distilling research notes into a prose narrative." ${ }^{37}$ Furthermore, students learned to work in team situations, how to work with various media, how to do mission- and community-oriented research, and how to keep their integrity "when under pressure to produce desired results rather than a history which is true to the facts." ${ }^{38}$ In addition to the first university program in public history, G. Wesley Johnson organized the first of several conferences about public history. The conferences, organized between 1978 and 1980, led to the founding of the National Council on Public History $(\mathrm{NCPH})$, which became and remains the main association for public historians in the US. Furthermore, in 1978, Johnson published the first edition of The Public Historian, a journal entirely devoted to public history. ${ }^{39}$ Today, there are more than 200 public history study programs in the US. Even in Germany, public history has recently become a field of historical research and practice. ${ }^{40}$ German academics had previously ignored popular forms and practices of history. The idea of applying history to the public contradicted the ideal of free scholarship and pure research at German universities. As a result, public history is still in a fledgling state. Only a few universities in Germany offer study programs in public history: In 2008, the first public history graduate program started at the Freie Universität Berlin; in 2015 and 2016, the Universities in Cologne and Bochum launched their own programs. The University of Heidelberg is also launching a new public history program. These programs prepare public historians in-the-making for various assignments like preserving historic buildings, making historical documentaries, or designing historical journals, books, or exhibitions. Even consulting creators of historical - or history-based - dramas in theater and television is part of their job description.

A 2008 survey demonstrates the variety of hosting agencies and institutions for public historians in the US. For instance, museums (23.8\%), state governments (9\%), historical organizations $(8.9 \%)$, the federal government $(8.5 \%)$, research

35 See Kelley, "Public History," 19.

36 See Otis L. Graham Jr. "Robert Kelley and the Pursuit of Useful History," Journal of Policy History 23 (2011): 429-437.

37 Kelley, "Public History," 25.

38 Kelley, "Public History," 24.

39 See Cauvin, Public History, 9. See also Alfred J. Andrea. “On Public History." The Historian 53 (1991): 384.

40 See Martin Lücke and Irmgard Zündorf. Einführung in die Public History (Göttingen: Vandenhoeck \& Ruprecht, 2018). See also Frank Bösch and Constantin Goschler (ed.). Public History. Öffentliche Darstellung des Nationalsozialismus jenseits der Geschichtswissenschaft (Frankfurt am Main: Campus, 2009). See also Simone Rauthe. Public History in den USA und der Bundesrepublik Deutschland (Essen: Klartext, 2001). 
centers $(5.1 \%)$, businesses $(2.9 \%)$, and many more. ${ }^{41}$ Obviously, "outside academia" describes a wide range of opportunities and employers for public historians. Nevertheless, the employment of public historians does not say anything about the nature of their work. Hence, defining the term public history is still a difficult task.

One American definition of public history exemplifies the field's shifting focus: "history for the public, about the public and by the public" ${ }^{2}$ : "History by the public" refers to the tradition of local historians and the participation of ordinary people (without formal historiographical training) in historical research. This means on the one hand that ordinary people, their personal stories, and memories are the focal point of historical research. On the other hand, "history by the public" also describes collaborations between historians and non-academic audiences. Thus, historical research as "history by the public" also encompasses the history workshop movement in Britain in 1970s and the citizen science movement today. ${ }^{43}$

"History about the public" seems to be comparable to Rüsen's concept of historical culture: It concentrates on the presentation and interpretation of history in the public domain and the media and is interested in the historical consciousness of a society. While Rüsen's concept works as a theoretical framework and focuses on ideal-typical dimensions and analyzing different cultural ways of doing history, public history also includes pragmatic and professional aspects. In this sense, "history for the public" stands for the academic training of professional public historians to gain "historical skills and perspectives in the service of a largely nonacademic clientele." ${ }^{4} 4$ This use of methods and skills to practice history in the public domain is also called applied history. ${ }^{45}$ History is applied to present issues,

41 John Dichtl and Robert B. Townsend. "A Picture of Public History: Preliminary Results from the 2008 Survey of Public History Professionals." Perspectives on History, September 1, 2009, URL: https://www.historians.org/publications-and-directories/perspectives-on-history/september-2009/a-picture-of-public-history (accessed September 9, 2019).

42 Charles C. Cole. "Public History: What difference has it made?" The Public Historian 16 (1994): 11.

43 See Raphael Samuel. (ed). History Workshop: A Collectanea, 1967-1991: Documents, Memoirs, Critique and Cumulative Index to History Workshop Journal (Oxford: Ruskin College, 1991). See also Sina Speit. "Public History und historische Grundlagenforschung. Das Projekt "Die Geschichte der Landesministerien in Baden und Württemberg in der Zeit des Nationalsozialismus, " in Bürger, Künste, Wissenschaft. Citizen Science in Kultur und Geisteswissenschaften, ed. by Kristin Oswald and René Smolarski (Gutenberg: Computus Druck Satz \& Verlag, 2016): 119-137. See also Alan Irwin. Citizen Science. A Study of People, Expertise and Sustainable Development (London, New York: Routledge, 1995).

44 Andrea, "On Public History," 381.

45 See Irmgard Zündorf. "Public History und Angewandte Geschichte - Konkurrenten oder Komplizen?” in Angewandte Geschichte. Neue Perspektiven auf Geschichte in der Öffentlichkeit, ed. by Jacqueline Nießer and Juliane Tomann (Paderborn: Schöningh, 2014): 63-76. - Rüsen considers 
audiences, actors, and policies. Public historians are well aware that history can be used and distorted for many different purposes. Thus, the main challenge is handling the tension "between historian's interest in educating audiences and the commercial interest in providing leisure." 46 Acknowledging the broad range of activities public historians tackle, this last aspect clearly shows an educational dimension. Public historians raise questions und unsettle established views. In this sense, they contribute immensely to civics education (politische Bildung).

\section{Below the Highbrow: Popular History}

"[P]ublic history is popular history - it is seen or read by large numbers of people and has mostly been designated for a mass audience." ${ }^{77}$ In fact, the term popular history is sometimes used synonymously with "Public" or "Applied History." Barbara Korte and Sylvia Paletschek define popular history as "all forms of historical presentation in written, audio/visual, artefactual and performative modes which address a broad, non-expert audience." 48 To differentiate "Public" and "Popular" history, it might be helpful to look at historical representations and their recipients more closely.

While public history is often tied to high cultural institutions like museums, archives or libraries, popular history arises "below" the highbrow level. As part of popular culture, popular history is often presented by mass media and geared towards the interests, needs, and desires of its audiences. Normally, there is neither a curatorial or pedagogical framework, nor an educational agenda. Popular representations of history mainly pursue entertainment and economic goals. Nevertheless, they inform and educate audiences about history. They have a way of influencing attitudes towards certain topics and a considerable impact on the formation of historical consciousness. Television, for example, "has become the closest most people will get, or even want to get, to experiencing history." ${ }^{49}$ Critics often consider popular history trivial and dumbed-down. ${ }^{50}$ They warn of the

the concept "Applied History" ambiguous, since it is not about actually applying historical knowledge. He therefore recommends the term "Practical History" (Praktische Geschichte). - See Jörn Rüsen and Juliane Tormann. "Geschichtskultur und Angewandte Geschichte," in Angewandte Geschichte. Neue Perspektiven auf Geschichte in der Öffentlichkeit, ed. by Jacqueline Nießer and Juliane Tomann (Paderborn: Schöningh, 2014), 58-62.

46 Cauvin, Public History, 13.

47 Ludmilla Jordanova. History in Practice. $2^{\text {nd }}$ edition (London: Hodder Education, 2006). 126.

48 Korte and Paletschek, "Historical Edutainment," 195.

49 Sayer, Public History, 92.

50 See Janet Coles and Paul Armstrong. "Dumbing down history through popular culture: communities of interest or learning as consumption?” 37th Annual SCUTREA Conference. Queen's Univer- 
immersive experience that hinders opportunities to evaluate the presented historical interpretations critically. With words like "Docutainment" or "Edutainment," critics frequently point out the problematic combination of historical documentation and entertainment with respect to the tension between educating audiences and the requirements of drama. ${ }^{51}$

In Germany, academic scholars long ignored or frowned upon entertaining and popular forms of history and popular culture in general. The educated classes in Germany used to define themselves more rigorously against everything "popular" than their American counterparts did, and this was supported by the rejection of mass culture promoted by leading intellectuals, most notably Theodor W. Adorno. He bemoaned that leisure time had fallen into the hands of an omnipresent entertaining machine, which he dubbed the "culture industry": modern films, television, radio, and magazines seemed, for Adorno, almost designed to keep audiences distracted, unable to understand themselves, and without the will to change social reality.

Nevertheless, this kind of criticism neglects and demotes the audience's perspective and its critical abilities. Adorno's one-sided view on popular culture reduces audiences to "victims" of the culture industry. However, audiences are not merely passive consumers, but rather creative recipients. Adorno's depiction of popular culture ignores that different media and genres not only affect audiences differently; it overlooks the fact that viewers and readers use popular culture for various reasons and under changing circumstances. ${ }^{52}$ Furthermore, this type of one-sided research often only analyzes the historical accuracy of popular representations of history and completely neglects aesthetic aspects. ${ }^{53}$

At the 2006 Conference of German Historians (Deutscher Historikertag) in Konstanz, scholars addressed the popularization of history in television. However, it would be an oversimplification to dismiss popular history merely as popularization or entertainment. Indeed, the use, effects, forms, and history of popular historical representations are a multilayered phenomenon which requires a multi- and interdisciplinary analysis: This new development received considerable input from the field of cultural studies, as well as literary, visual, media, and performance studies.

sity, Belfast, Northern Ireland, 2007. URL: http://www.leeds.ac.uk/educol/documents/163834. htm (accessed July 10, 2019).

51 See Oliver Näpel. "Historisches Lernen durch 'Dokutainment'? - Ein geschichtsdidaktischer Aufriss. Chancen und Grenzen einer neuen Ästhetik populärer Geschichtsdokumentationen analysiert am Beispiel der Sendereihen Guido Knopps." Zeitschrift für Geschichtsdidaktik 2 (2003): 233-235.

52 See David Morley. Television, Audiences and Cultural Studies (London: Routledge, 1992), 173197.

53 Gerhard Paul. "Einführung," in Zeitgeschichte - Medien - Historische Bildung, ed. by Susanne Popp, Michael Sauer, Berrina Alavi, Marko Demantowsky, Gerhard Paul (Göttingen: V\&R unipress, 2010), 194. 
Today, researchers acknowledge that popular historical representations are narrativized, dramatized, personalized, and emotionalized. ${ }^{54}$ "Nevertheless," Mario Carretero, Stefan Berger, and Maria Grever state, "it is striking that the research agendas of historical discipline, the philosophy of history, history education and popular historical culture are still separate." ${ }^{55}$ It seems to be necessary on the one hand to reevaluate the relationship between academic history, popular media, and education, while on the other hand, the misleading notion of films and television teaching audiences lessons from history clearly needs to be revised.

\section{Research Levels of Historical Representations in Popular Media and Education}

A juxtaposition and comparison of the North American tradition of public history with the development of German history didactics, especially the concept of historical culture, reveals different emphases, deficits, and overlaps. At the same time, a synopsis of the different approaches illuminates four ideal levels for researching historical representations in popular media and their ties to education: a multi-disciplinary and analytical, a socio- or culture-theoretical, a pragmatic, and a historiographical level.

On the analytical level, first of all, a substantive and formal investigation of the medium (play, film, or television series) takes place. In this case, the analysis should not be concerned with checking the correctness of the historical events presented, but rather with examining the aesthetic and medial means of producing historical authenticity. The second level explores how viewers perceive the medium, what effects it has on them, and how they evaluate it. The aim is to determine which historical images shape their ideas of history, whether these images influence their interpretation of the present, and whether they have an influence on their anticipations of the future. Additionally, this level can ask if the audience's prior historical knowledge is called into question by these images. On the third level, pragmatic considerations can be made about how the medium can become educational in order to foster historical learning. It can also be asked if the medium should be accompanied by additional educational measures. Finally, these examination steps can be historicized themselves. If the medium is not a contemporary production, then at the final level of investigation, its historical context may be used to ask how history has been made accessible. All these levels

54 See Korte and Paletschek, "Historical Edutainment," 195.

55 Mario Carretero, Stefan Berger, and Maria Grever. "Introduction: Historical Cultures and Education in Transition," in Palgrave Handbook of Research in Historical Culture and Education, ed. by Mario Carretero, Stefan Berger, and Maria Grever (London: Palgrave Macmillan, 2017), 2. 
of investigation can be found in the following contributions to this anthology in one way or another.

\section{Cited Works}

Andrea, Alfred J. “On Public History.” The Historian 53 (1991): 381-386.

Assmann, Jan. "Communicative and Cultural Memory," in Cultural Memory Studies. An International and Interdisciplinary Handbook, ed. by Astrid Erll and Ansgar Nünning (Berlin, New York: De Gruyter, 2008), 109-118.

Assmann, Jan. "Collective Memory and Cultural Identity." New German Critique 65 (1995): 125-133.

Bösch, Frank and Constantin Goschler (ed.). Public History. Öffentliche Darstellung des Nationalsozialismus jenseits der Geschichtswissenschaft. Frankfurt am Main: Campus, 2009.

Bush, Rebecca and K. Tawny Paul. Art and Public History. Approaches, Opportunities, and Challenges. Lanham: Rowman \& Littlefield, 2017.

Cauvin, Thomas. Public History. A Textbook of Practice. New York, London: Routledge, 2016.

Carretero, Mario, Stefan Berger, and Maria Grever. "Introduction: Historical Cultures and Education in Transition," In Palgrave Handbook of Research in Historical Culture and Education, ed. by Mario Carretero, Stefan Berger, and Maria Grever (London: Palgrave Macmillan, 2017), 1-35.

Cole, Charles C. "Public History: What difference has it made?" The Public Historian 16 (1994): 9-35.

Coles, Janet and Paul Armstrong. "Dumbing down history through popular culture: communities of interest or learning as consumption?" 37th Annual SCUTREA Conference. Queen's University, Belfast, Northern Ireland, 2007, http://www.leeds.ac.uk/educol/documents/163834.htm (accessed July 10, 2019).

Dichtl, John and Robert B. Townsend. "A Picture of Public History: Preliminary Results from the 2008 Survey of Public History Professionals.” Perspectives on History, September 1, 2009, URL: https:// www.historians.org/publications-and-directories/perspectives-on-history/september-2009/a-picture-of-public-history (accessed September 9, 2019).

Graham Jr., Otis L. "Robert Kelley and the Pursuit of Useful History." Journal of Policy History 23 (2011): 429-437.

Grever, Maria, and Adriaansen, Robert-Jan. "Historical Culture: A Concept revisited," in Palgrave Handbook of Research in Historical Culture and Education, ed. by Mario Carretero, Stefan Berger, and Maria Grever (London: Palgrave Macmillan, 2017), 73-89.

Hackney, Sheldon, Anne Frior Scott, Bertram Wyatt-Brown, William S. McFeely, and Lawrence N. Powell. “C. Vann Woodward, 1908-1999: In Memoriam.” Journal of Southern History 66 (2000): 207-220.

Irwin, Alan. Citizen Science. A Study of People, Expertise and Sustainable Development. London, New York: Routledge, 1995.

Jeismann, Karl-Ernst. "Geschichtsbewußtsein als zentrale Kategorie der Didaktik des Geschichtsunterrichts," in Geschichte und Bildung. Beiträge zur Geschichtsdidaktik und zur Historischen Bildungsforschung, ed. by Wolfgang Jacobmeyer and Bernd Schönemann (Paderborn: Schöningh, 2000), 46-72.

Jeismann, Karl-Ernst. "Didaktik der Geschichte. Die Wissenschaft von Zustand, Funktion und Veränderung geschichtlicher Vorstellungen im Selbstverständnis der Gegenwart," in Geschichtswissenschaft. Didaktik - Forschung - Theorie, ed. by Erich Kosthorst (Göttingen: Vandenhoeck Ruprecht, 1977), 9-33.

Jordanova, Ludmilla. History in Practice. $2^{\text {nd }}$ edition. London: Hodder Education, 2006.

Kansteiner, Wulf. "Finding Meaning in Memory: A Methodological Critique of Collective Memory Studies." History and Theory 41 (2002): 179-197. 
Kelley, Robert. "Public History: Its Origins, Nature, and Prospects," The Public Historian 1 (1978): 16-28.

Korte, Barbara and Sylvia Paletschek. "Historical Edutainment: New Forms and Practices of Popular History?" in Palgrave Handbook of Research in Historical Culture and Education, ed. by Mario Carretero, Stefan Berger, and Maria Grever, 191-205. London: Palgrave Macmillan, 2017.

Korte, Barbara and Sylvia Paletschek. "Popular History Now and Then: An Introduction," in Popular History Now and Then. International Perspectives, ed. by Barbara Korte and Sylvia Paletschek (Bielefeld: transcript, 2012), 7-11.

Korte, Barbara, and Sylvia Paletschek. "Geschichte in populären Medien und Genres: Vom Historischen Roman zum Computerspiel," in History Goes Pop. Zur Repräsentation von Geschichte in Medien und Genres, ed. by Barbara Korte and Sylvia Paletschek,. (Bielefeld: transcript, 2009), 9-60.

Koselleck, Reinhart. "Historia Magistra Vitae. Über die Auflösung des Topos im Horizont neuzeitlich bewegter Geschichte," in Vergangene Zukunft. Zur Semantik geschichtlicher Zeiten (Frankfurt am Main: Suhrkamp, 1979), 38-66.

Lisson Gallery. "Christian Jankowski: Heavy Weight History,” 2014. URL: https://www.lissongallery. com/exhibitions/christian-jankowski-heavy-weight-history (accessed August 28, 2019).

Lowenthal, David. "History and Memory." The Public Historian 19 (1997): 31-39.

Lücke, Martin and Irmgard Zündorf. Einführung in die Public History. Göttingen: Vandenhoeck \& Ruprecht, 2018.

Morley, David. Television, Audiences \& Cultural Studies. London: Routledge, 1992.

Näpel, Oliver. "Historisches Lernen durch ,Dokutainment'? - Ein geschichtsdidaktischer Aufriss. Chancen und Grenzen einer neuen Ästhetik populärer Geschichtsdokumentationen analysiert am Beispiel der Sendereihen Guido Knopps.” Zeitschrift für Geschichtsdidaktik 2 (2003): 213-244.

Nießer, Jacqueline and Juliane Tomann (ed.). Angewandte Geschichte. Neue Perspektiven auf Geschichte in der Öffentlichkeit (Paderborn: Schöningh, 2014).

Paul, Gerhard. "Einführung," in Zeitgeschichte - Medien - Historische Bildung, ed. by Susanne Popp, Michael Sauer, Berrina Alavi, Marko Demantowsky, and Gerhard Paul (Göttingen: V\&R unipress, 2010), 193-200.

Rauthe, Simone. Public History in den USA und der Bundesrepublik Deutschland. Essen: Klartext, 2001.

Rüsen, Jörn. "Die fünf Dimensionen der Geschichtskultur," in Angewandte Geschichte. Neue Perspektiven auf Geschichte in der Öffentlichkeit, ed. by Jacqueline Nießer and Juliane Tomann (Paderborn: Schöningh 2014), 46-57.

Rüsen, Jörn and Juliane Tormann. "Geschichtskultur und Angewandte Geschichte," in Angewandte Geschichte. Neue Perspektiven auf Geschichte in der Öffentlichkeit, ed. by Jacqueline Nießer and Juliane Tomann (Paderborn: Schöningh, 2014), 58-62.

Rüsen, Jörn. "Geschichtskultur," in Handbuch der Geschichtsdidaktik. $5^{\text {th }}$ edition, ed. by Klaus Bergmann, Klaus Fröhlich, Annette Kuhn et al. (Seelze-Velber: Kallmeyer'sche Verlagsbuchhandlung, 1997), 38-41.

Rüsen, Jörn. "Geschichtsdidaktik heute - Was ist und zu welchem Ende betreiben wir sie (noch)?” in Bildungsgeschichte und historisches Lernen, ed. by Ernst Hinrichs and Wolfgang Jacobmeyer (Frankfurt am Main: Moritz Diesterweg, 1991), 9-23.

Rüsen, Jörn. "The Didactics of History in West Germany: Towards a New Self-Awareness of Historical Studies." History and Theory 26 (1987): 275-286.

Samida, Stefanie, Sarah Willner and Georg Koch. "Doing History - Geschichte als Praxis. Programmatische Annäherungen," in Doing History. Performative Praktiken in der Geschichtskultur, ed. by Sarah Willner, Georg Koch, and Stefanie Samida (Münster: Waxmann, 2016), 1-25

Samuel, Raphael (ed.). History Workshop: A Collectanea, 1967-1991: Documents, Memoirs, Critique and Cumulative Index to History Workshop Journal (Oxford: Ruskin College, 1991).

Sayer, Faye. Public History: A Practical Guide. London: Bloomsbury, 2019. 
Scardaville, Michael C. "Looking Backwards Toward the Future: An Assessment of the Public History Movement." The Public Historian 9 (1987): 35-43.

Schönemann, Bernd. "Erinnerungskultur oder Geschichtskultur?" in Kulturwissenschaft und Geschichtsdidaktik, ed. by Eugen Kotte (München: Martin Meidenbauer, 2011), 53-72.

Seixas, Peter. "Historical Consciousness and Historical Thinking," in Palgrave Handbook of Research in Historical Culture and Education, ed. by Mario Carretero, Stefan Berger, and Maria Grever (London: Palgrave Macmillan, 2017), 59-72.

Speit, Sina. "Public History und historische Grundlagenforschung. Das Projekt ,Die Geschichte der Landesministerien in Baden und Württemberg in der Zeit des Nationalsozialismus“,” in Bürger, Künste, Wissenschaft. Citizen Science in Kultur und Geisteswissenschaften, ed. by Kristin Oswald and René Smolarski (Gutenberg: Computus Druck Satz \& Verlag, 2016), 119-137.

Spring, Dawn. "Gaming history: computer and video games as historical scholarship." Rethinking History. Journal of Theory and Practice, 19 (2015): 207-221.

Stearns, Peter N. and Joel A. Tarr. "Curriculum in Applied History: Toward the Future." The Public Historian 9 (1987): 111-125.

Thorp, Robert. "Popular history magazines and history education." Historical Encounters: A journal of historical consciousness, historical cultures, and history education, 2 (2015): 102-12.

Veysey, Laurence. “The 'New' Social History in the Context of American Historical Writing." Reviews in American History 17.1 (1979): 1-12. 